\title{
Evaluation of the normal choroid plexus size in adults with Magnetic Resonance Imaging
}

\section{Koroid pleksus normal boyutunun erişkinlerde Magnetik Rezonans Görüntüleme ile değerlendirilmesi}

\author{
Hakan İmamoğlu*, Mustafa Fatih Erkoç, İsmail Şalk, Aylin Okur, \\ Eylem Itır Aydemir
}

Clinical Radiology (H. İmamoğlu, MD, M. F. Erkoç, MD), Numune Hospital, TR-58040 Sivas, Department of Radiology (Assist. Prof. İ. Şalk, MD), Cumhuriyet University School of Medicine, TR-58140 Sivas, Department of Radiology (Assist. Prof. A. Okur, MD), Bozok University School of Medicine, TR-66200 Yozgat, Department of Statistics (E. I. Aydemir, MD), Cumhuriyet University Faculty of Science, TR-58140 Sivas

\begin{abstract}
Aim. According to our knowledge, there is no definition for the normal choroid plexus (CP) size with magnetic resonance imaging (MRI) in adults. The aim of this study was to evaluate the normal CP size in the adult population. The data for normal size may help to evaluate the early diagnosis of CP pathologies. Methods. The measurements were obtained retrospectively from 380 MRIs. The thickness of CP was evaluated in eight locations from different two planes for each study. The exclusion criterions were; absent or inadequate demonstration of $\mathrm{CP}$ and the existence of $\mathrm{CP}$ pathologies. Means and ranges of $\mathrm{CP}$ thickness were evaluated in different gender, age groups and also in general population. Comparisons were made between genders, age groups and between the thickness from left and right. Results. The mean CP thickness was found $2.22 \mathrm{~mm}$, $4.63 \mathrm{~mm}$ and $1.95 \mathrm{~mm}$ in body, atrium of lateral ventricles and in fourth ventricles respectively. There was no significative difference between gender and the thickness from left and right. Conclusion. Various CP pathologies can occur in adults. To know the normal CP size may help to early diagnosis of CP pathologies that can be very important.
\end{abstract}

Keywords: Brain, Choroid plexus size, magnetic resonance imaging

\section{Özet}

Amaç. Bizim bilgimize göre erișkinlerde magnetik rezonans görüntüleme (MRG) ile normal koroid pleksus (KP) boyut tanımı yoktur. Bu çalışmanın amacı erişkin popülasyonda normal boyutun değerlendirilmesidir. Bu normal boyut verileri KP patolojilerinin erken tanısına yardımcı olabilir. Yöntem. Ölçümler retrospektif olarak 380 MRG' den elde edildi. KP kalınlığı her çalışmada iki ayrı planda 8 lokalizasyonda değerlendirildi. Dışlama kriterleri; KP'nin görüntülenememesi veya yetersiz görüntülenmesi ve KP patolojilerinin bulunmasıydı. KP kalınlığının ortalaması ve dağılımı farklı cinsiyet ve yaş gruplarında ve aynı zamanda genel populasyonda değerlendirildi. Cinsiyet, yaş grupları ve sağ, sol kalınlıklar arası karşılaştırmalar yapıldı. Bulgular. Ortalama KP kalınlığ 1 lateral ventrikül korpusu, atriumu ve dördüncü ventrikülde sırasıyla $2.22 \mathrm{~mm}, 4.63 \mathrm{~mm}$ ve $1.95 \mathrm{~mm}$ olarak bulundu. Cinsiyet ile sağda ve solda kalınlıklar arası anlamlı farklılık yoktu. Sonuç. Erişkinlerde çeşitli KP patolojileri görülebilir. Normal KP boyutunu bilme, çok önemli olabilen KP patolojilerinin erken tanısına yardım edebilir.

Anahtar sözcükler: Beyin, Koroid pleksus boyutu, magnetik rezonans görüntüleme

Geliş tarihi/Received: July 30, 2012; Kabul tarihi/Accepted: February 21, 2013

*Corresponding author:

Dr. Hakan İmamoğlu, Radyoloji Kliniği, Numune Hastenesi, TR-58040 Sivas. E-mail: drhimamoglu@ hotmail.com 


\section{Introduction}

Choroid plexus $(\mathrm{CP})$ is a tiny structure in ventricles of central nervous system. Its weight is only $2 \mathrm{~g}$. However its small size, $\mathrm{CP}$ plays a vital role because it secretes approximatelly $600 \mathrm{ml}$ of cerebrospinal fluid for each day. Studies that search the CP size with magnetic resonance imaging (MRI) are limited. A few studies evaluate the CP size in children [1-3] but no studies were found in English language literature that evaluates the $\mathrm{CP}$ size by using MRI in adults. The pathologies of CP can occur as a focal or diffuse lesion. To determine the normal size of $\mathrm{CP}$ in adults can help the early diagnosis of these lesions. The size of CP was evaluated in different location and planes in this study.

\section{Materials and methods}

Institutional Review Board approval was obtained. 380 MRI studies were retrospectively searched. They were obtained with 1.5 T (Magnetom Symphony, Siemens, Germany) MRI machine. The exclusion criterions were; absent or inadequate demonstration of CP and the existence of CP pathologies. MRI studies were included T1- Weighted (T1W) axial, T2- Weighted (T2W) axial, fluid attenuated inversion recovery (FLAIR) axial and T1W sagittal nonenhanced images. Measurements were done as a thickness by an experienced radiologist. The location of measurements were in the body and atrium of lateral ventricles from right and left, and also in fourth ventricle on axial images and in the body of lateral ventricles from right and left and in the fourth ventricle on sagittal images (Figure 1). FLAIR axial and T1W sagittal images were used for axial and sagittal measurement. Seven age groups were formed for comparison. Means and ranges of CP thickness were evaluated in different gender, age groups and also in general population. Comparisons were made between genders, age groups and between the thickness from left and right. SPSS 19 statistical package was used for statistical analysis. Anova was used for comparison of age groups and t test was used for comparison of gender and the thickness from right and left. A p value $<0.05$ was considered statistically significant.
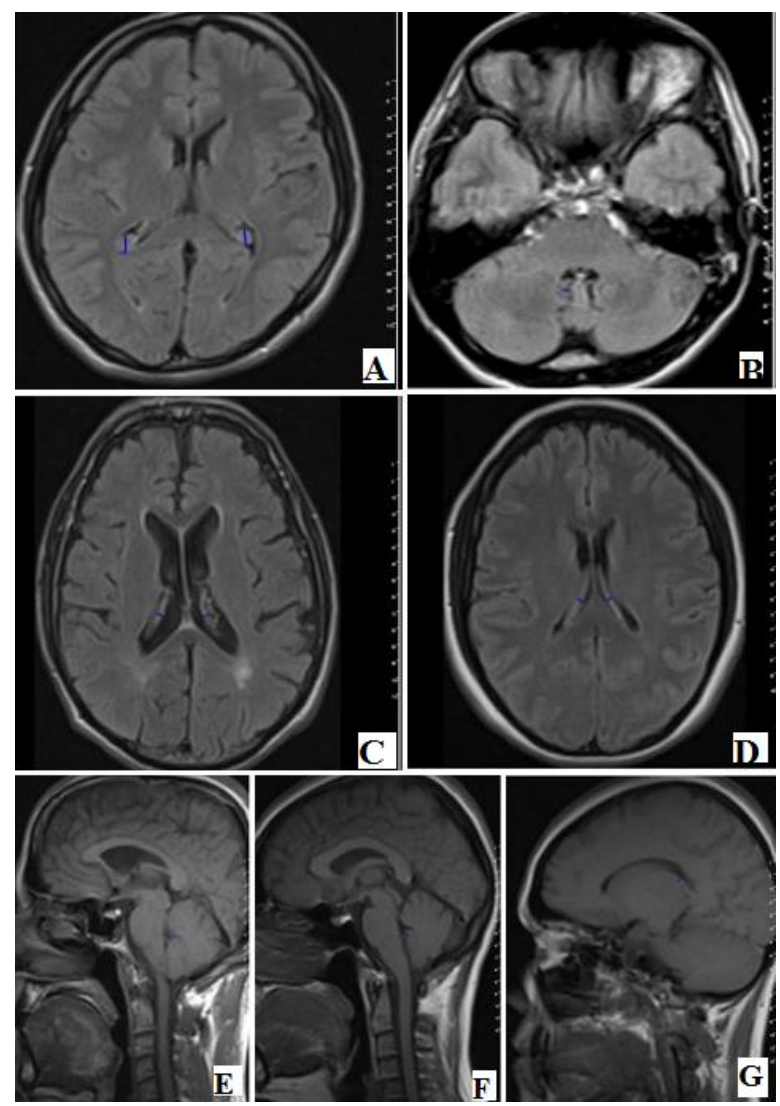

Figure 1. Blue lines show the location of measurement on axial (A, B, C, D) and sagittal (E, F, G) planes. 


\section{Results}

The adults ranged in age from 18 to 85 years (mean: $44.31 \pm 17.14) .218$ (62\%) adults were female (mean age $44.49 \pm 16.53$ ) and $130(38 \%)$ were male (mean age $44.0 \pm 18.16)$. There were seven age groups. They have 54 (15.5\%), 54 (15.5\%), 69 (19.8\%), 71 (20.4\%), 48(13.8\%), 35 (10.1\%), 17 (4.9\%) adults respectively. Thirty-two MRI studies were excluded from the study because of the partial volume averaging effect and absence of the CP views in different planes. The mean CP thickness was found $2.22 \mathrm{~mm}, 4.63 \mathrm{~mm}$ and $1.95 \mathrm{~mm}$ in body, atrium of lateral ventricles and in fourth ventricles respectively. The values of measurement from 8 different places were shown in Table 1. There was no significative difference between gender and the thickness from left and right $(p>0.05)$. Difference was found only in atrium of lateral ventricle between second and sixth age group. There was no difference between other age groups so this data was accepted as adventitious.

Table 1. The thickness of choroid plexus in female, male and general population.

\begin{tabular}{lllllll}
\hline & \multicolumn{2}{c}{ Female } & \multicolumn{2}{c}{ Male } & \multicolumn{2}{c}{ General population } \\
\cline { 2 - 7 } & $\begin{array}{l}\text { Mean } \\
(\mathbf{m m})\end{array}$ & $\begin{array}{l}\text { Standard } \\
\text { deviation }\end{array}$ & $\begin{array}{l}\text { Mean } \\
(\mathbf{m m})\end{array}$ & $\begin{array}{l}\text { Standard } \\
\text { deviation }\end{array}$ & $\begin{array}{l}\text { Mean } \\
(\mathbf{m m})\end{array}$ & $\begin{array}{l}\text { Standard } \\
\text { deviation }\end{array}$ \\
\hline Axial body ( R ) & 2.3459 & 0.42111 & 2.2862 & 0.40553 & 2.3236 & 0.41578 \\
Axial body ( L ) & 2.3252 & 0.42378 & 2.3492 & 0.46842 & 2.3342 & 0.44047 \\
Axial atrium ( R ) & 4.5138 & 1.19075 & 4.7977 & 1.23373 & 4.6198 & 1.21303 \\
Axial atrium ( L ) & 4.5317 & 1.29727 & 4.8323 & 1.42998 & 4.644 & 1.35419 \\
Sagittal body ( R) & 2.0899 & 0.26982 & 2.1300 & 0.22017 & 2.1049 & 0.25283 \\
Sagittal body ( L ) & 2.1028 & 0.27906 & 2.0969 & 0.21564 & 2.1006 & 0.25689 \\
Sagittal 4.ventricle & 2.0165 & 0.40606 & 2.0677 & 0.43973 & 2.0356 & 0.41906 \\
Axial 4.ventricle & 1.8408 & 0.36937 & 1.9238 & 0.51426 & 1.8718 & 0.43041 \\
\hline R: Right L:Left & \multicolumn{7}{c}{} & & & & \\
\hline
\end{tabular}

\section{Discussion}

Double layer pia mater (tela choroidea) and ependymal structure together form $\mathrm{CP}$ in ventricles. $\mathrm{CP}$ is richly vasculer structure and appears red due to the blood in the stromal vessels. The pathologies of $\mathrm{CP}$ are neoplasms (papilloma, leukaemia, meningioma, lymphoma and metastases), infections (bacterial, fungal and viral), cysts, haemorrhage, congenital abnormalities (Sturge-Weber syndrome, Klippel-Trenaunay syndrome and vasculer malformations) and non-infectious inflammatory disorders (xanthogranulomas, inflammatory pseudotumour, neurosarcoidosis, rheumatoid nodule and villous hypertrophy) [4]. There are important discrepancies in terms of lesions between children and adults. Papilloma generally occurs in atrium of lateral ventricle and fourth ventricle in children and adults respectively. Metastases usually originate from Wilm's tumour, neuroblastoma and retinoblastoma in children [5] and from gastric cancer and lung cancer in adults [6]. Menengiomas usually occur in adults and originate from lateral ventricles. Lymphomas appear in all ages. Cysts commonly occur in children and adults less than 40 years of age. Infections (choroid plexitis) can occur primarily or secondarily. Infections were published in adults with immunosuppression [7, 8]. CP is isodense to grey matter on nonenhanced computed tomography (CT) and isointense to grey matter on nonenhanced MRI. When calcification occurs in CP, it will be hyperdense on CT and hypointense on MRI. CP appears intermediate signal intensity on proton density and T2W MRI. Because $\mathrm{CP}$ is a richly vasculer structure, it enhances homogeneously after intravenous contrast medium injection on both CT and MRI [9-11]. MRI is favourite imaging modality because it is better than CT to show the location and relationship of the lesion [12].

Studies that search the CP size with MRI are limited. Madhukar et al. [1] evaluated the size of the normal CP on 71 MRIs and 26 ultrasounds in children. Two different studies evaluated the size of the CP in children with Sturge-Weber syndrome [2, 3]. No studies were found in English language literature that evaluates the CP size by using MRI in adults. 
$\mathrm{CP}$ size and thickness did not showed significant difference between genders and the thickness from left and right ( $>>0.05)$. Difference was found only in atrium of lateral ventricle between second and sixth age group in this study. There was no difference between other age groups so this data was accepted as adventitious.

The paucity of the number of MRI studies that examined can be the limitation of this study. But the number of observation in this study was bigger than the other similar studies in children. MRI studies that examined were nonenhanced studies. This can be the other limitation of this study because other similar studies were enhanced studies that can be better than this study for demonstration of CP. Routine nonenhanced studies were evaluated because it was considered that contrast medium can magnify the size of $\mathrm{CP}$.

Various CP pathologies can occur in adults. To know the normal CP size may help to early diagnosis of $\mathrm{CP}$ pathologies that can be very important.

\section{References}

1. Madhukar M, Choudhary AK, Boal DK, Dias MS, Iantosca MR. Choroid plexus: normal size criteria on neuroimaging. Surg Radiol Anat 2012; 34: 887-95.

2. Griffiths PD, Blaser S, Boodram MB, Armstrong D, Harwood-Nash D. Choroid plexus size in young children with Sturge-Weber syndrome. AJNR Am J Neuroradiol 1996; 17: 175-80.

3. Stimac GK, Solomon MA, Newton TH. CT and MR of angiomatous malformations of the choroid plexus in patients with Sturge-Weber disease. AJNR Am J Neuroradiol 1986; 7: 623-7.

4. Guermazi A, De Kerviler E, Zagdanski AM, Frija J. Diagnostic imaging of choroid plexus disease. Clin Radiol 2000; 55: 503-16.

5. Pear BL. Xanthogranuloma of the choroid plexus. AJR Am J Roentgenol 1984; 143: 401-2.

6. Nakabayashi H, Murata K, Sakaguchi M, Nakajima K, Katsuyama J. Choroid plexus metastasis from gastric cancer--case report. Neurol Med Chir (Tokyo) 1994; 34: 183-6.

7. Guermazi A, Miaux Y, Laval-Jeantet M. Imaging of choroid plexus infection by Stomatococcus mucilaginosus in neutropenic patients. AJNR Am J Neuroradiol 1995; 16: 1331-4.

8. Guermazi A, Miaux Y, Zagdanski AM, Laval-Jeantet M. Choroid plexitis caused by cytomegalovirus in a patient with AIDS. AJNR Am J Neuroradiol 1996; 17: 1398-9.

9. Kilgore DP, Breger RK, Daniels DL, Pojunas KW, Williams AL, Haughton VM. Cranial tissues: normal MR appearance after intravenous injection of Gd-DTPA. Radiology 1986; 160: 757-61.

10. Naidich TP, Pudlowski RM, Leeds NE, Naidich JB, Chisolm AJ, Rifkin MD. The normal contrast-enhanced computed axial tomogram of the brain. J Comput Assist Tomogr 1977; 1: 16-29.

11. Hinshaw DB Jr, Fahmy JL, Peckham N, Thompson JR, Hasso AN, Holshouser B, Paprocki T. The bright choroid plexus on MR: CT and pathologic correlation. AJNR Am J Neuroradiol 1988; 9: 483-6.

12. Coates TL, Hinshaw DB JR, Peckman N, Thompson JR, Hasso AN, Holshouser BA, Knierim DS. Pediatric choroid plexus neoplasms: MR, CT, and pathologic correlation. Radiology 1989; 173: 81-8. 